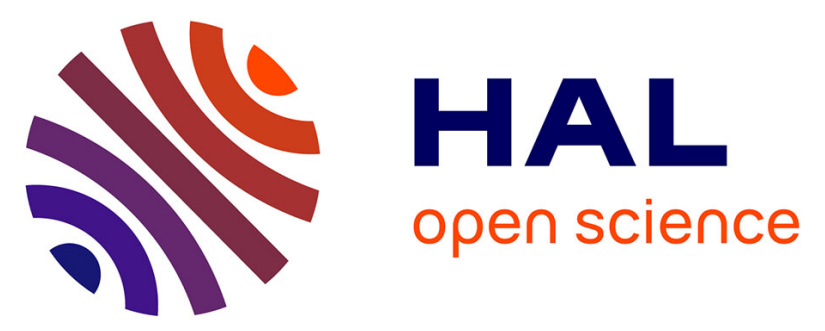

\title{
A combined thermodynamic/experimental study for the optimisation of hydrogen production by catalytic reforming of isooctane
}

Laurent Villegas, Nolven Guilhaume, H. Provendier, Cecile Daniel, Frédéric

Masset, Claude Mirodatos

\section{To cite this version:}

Laurent Villegas, Nolven Guilhaume, H. Provendier, Cecile Daniel, Frédéric Masset, et al.. A combined thermodynamic/experimental study for the optimisation of hydrogen production by catalytic reforming of isooctane. Applied Catalysis A: General, 2005, 281 (1-2), pp.75-83. 10.1016/j.apcata.2004.11.015 . hal-00012855

\section{HAL Id: hal-00012855 https://hal.science/hal-00012855}

Submitted on 4 Jan 2022

HAL is a multi-disciplinary open access archive for the deposit and dissemination of scientific research documents, whether they are published or not. The documents may come from teaching and research institutions in France or abroad, or from public or private research centers.
L'archive ouverte pluridisciplinaire HAL, est destinée au dépôt et à la diffusion de documents scientifiques de niveau recherche, publiés ou non, émanant des établissements d'enseignement et de recherche français ou étrangers, des laboratoires publics ou privés.

\section{(ㄷ)(1) $\$$}

Distributed under a Creative Commons Attribution - NonCommerciall 4.0 International 


\title{
A combined thermodynamic/experimental study for the optimisation of hydrogen production by catalytic reforming of isooctane
}

\author{
L. Villegas ${ }^{\mathrm{a}}, \mathrm{N}$. Guilhaume ${ }^{\mathrm{b}, *}$, H. Provendier ${ }^{\mathrm{b}}$, \\ C. Daniel ${ }^{\mathrm{b}}$, F. Masset ${ }^{\mathrm{a}}$, C. Mirodatos ${ }^{\mathrm{b}}$ \\ a PSA Peugeot Citroën, 2 Route de Gisy, F-78943 Velizy Villacoublay Cedex, France \\ ${ }^{\mathrm{b}}$ Institut de Recherche sur la Catalyse, 2 Avenue Albert Einstein, F-69626 Villeurbanne Cedex, France
}

\begin{abstract}
The reforming of isooctane in the presence of both steam and oxygen (autothermal reforming, ATR) has been investigated over a Pt/ceriazirconia catalyst. The aim of this study was to determine the gas feed composition corresponding to an optimum hydrogen production, by using thermodynamic calculations as well as experimental data. Thermodynamic calculations based on energy and component balances show that the ATR of isooctane should be the most efficient with an $\mathrm{O} / \mathrm{C}$ ratio close to 1 and an $\mathrm{H}_{2} \mathrm{O} / \mathrm{C}$ ratio around 2. The experimental study corroborates the calculations: at constant $\mathrm{H}_{2} \mathrm{O}$ introduction, increasing the $\mathrm{O} / \mathrm{C}$ ratio in the feed improves isooctane conversion, but at the expense of the $\mathrm{H}_{2}+\mathrm{CO}$ selectivity. The optimum $\mathrm{O} / \mathrm{C}$ ratio is obtained between 0.75 and 1 . The steam-to-carbon ratio also has an important impact on hydrogen production, in this case not related to a strong improvement in the conversion of isooctane, but rather to the displacement of the WGS equilibrium. Under optimised feed gas composition and high space velocity $\left(150000 \mathrm{~h}^{-1}\right)$, the reaction reaches the thermodynamic equilibrium at $730{ }^{\circ} \mathrm{C}$. The good stability of the catalytic activity under reaction conditions suggests that, although a sintering of both support and platinum was evidenced in the used catalyst, this modification probably takes place rapidly at the first exposure to high temperature and steam. There is no evidence for carbon poisoning of the catalyst when used under optimised feed composition.
\end{abstract}

Keywords: Hydrogen; Fuel cell; Catalytic reforming; Isooctane; Gasoline; $\mathrm{Pt} / \mathrm{Ce}_{0.67} \mathrm{Zr}_{0.33} \mathrm{O}_{2}$

\section{Introduction}

Polymer electrolyte membrane (PEM) fuel cells are considered as one of the most promising technology to replace the internal combustion engine in vehicles. This application requires fast cold-start, high current density and fast response to power variations, which are difficult to obtain with other types of fuel cells (alkaline, phosphoric acid, molten carbonates, solid oxides). The PEM fuel cell, however, requires hydrogen as fuel. Since CO is a strong poison for the platinum fuel cell's electrodes, the $\mathrm{CO}$ content

\footnotetext{
* Corresponding author. Tel.: +33 4724453 89; fax: +33 472445399 . E-mail address: guilhaum@catalyse.cnrs.fr (N. Guilhaume).
}

in hydrogen must remain below $10 \mathrm{ppm}$ under steady state operation.

The lack of infrastructure for hydrogen production and distribution, as well as the current cost of hydrogen production from nuclear or renewable energy, has led car manufacturers to consider on-board generation from various hydrocarbons. On-board reforming of gasoline, which already presents a well-developed distribution network, is particularly interesting for a more efficient utilization of energy in vehicles, compared to internal combustion engines. Indeed, the energy yield of thermal engines is limited by the Carnot heat-to-work cycle, which is $40 \%$ for the best machines like steam turbines. In automotive applications, this yield is often less than $30 \%$ with gasoline 
spark-ignition engines, whereas it reaches $35 \%$ with high pressure direct injection diesel engines in their best operating range. In comparison, fuel cells produce electricity directly from chemical energy with a much higher efficiency (theoretically close to unity), which can effectively reach $50-60 \%$ for hydrogen-based fuel cells.

Hydrogen production by autothermal reforming (ATR) of light hydrocarbons $\left(\mathrm{C}_{1}-\mathrm{C}_{3}\right)$ has attracted much attention recently [1-3]. Calculations have shown the interest of coupling endothermic steam reforming with exothermic partial oxidation, in terms of reformer efficiency. Moreover, the feed stoichiometry can be tuned to adapt to cold start or changes in the power demand [4]. The appropriate choice of $\mathrm{O} / \mathrm{C}$ and $\mathrm{H}_{2} \mathrm{O} / \mathrm{C}$ ratios also allows the reaction to proceed without external heating. Important parameters for the reaction are temperature, pressure, $\mathrm{O} / \mathrm{C}$ and $\mathrm{H}_{2} \mathrm{O} / \mathrm{C}$ molar ratios. These parameters should be chosen with the aim of avoiding the formation of carbonaceous deposits, and of optimising hydrogen production, gasoline conversion and $\mathrm{H}_{2}+\mathrm{CO}$ selectivity.

With the objective of developing on-board reformers for automotive applications, this concept has been recently applied to the ATR of $n$-octane [5]. Ni catalysts had moderate activity in this reaction, whereas noble metal catalysts were more active, but deactivated under reaction conditions. A bimetallic Ni-Pd catalyst combined a high activity with good stability [5]. A Rh-based [6] catalyst deposited on metal sheets was tested in a monolithic reactor for the steam reforming and ATR of liquid hydrocarbons (isooctane, hexane, toluene). Krumpelt et al. also reported data obtained in a pilot-scale reformer $(10 \mathrm{~kW})$ working with isooctane [7]. However, experimental data on the ATR of liquid hydrocarbons remain scarce.

In this paper, as part of the development of a gasoline reformer, the reforming of isooctane, chosen as a model compound for gasoline, over a Pt catalyst supported on a $\mathrm{CeO}_{2}-\mathrm{ZrO}_{2}$ mixed oxide support, was investigated. This support was selected for its redox properties, which can promote noble metals activity, whereas its basic character is expected to limit carbon deposition in reforming reactions $[8,9]$. Ceria-zirconia mixed oxides also proved out to be active in the direct conversion of methane to synthesis gas [10]. The effect of the gas feed composition on the activity and stability of the catalyst is reported in this paper. Evolution of the catalyst under reaction conditions, but also good and resistance ability to carbon poisoning has been established.

\section{Experimental}

The ceria-zirconia support with composition $\mathrm{Ce}_{0.67} \mathrm{Zr}_{0.33} \mathrm{O}_{2}$ was prepared by coprecipitation of a $\mathrm{Ce}\left(\mathrm{NO}_{3}\right)_{3} \cdot 6 \mathrm{H}_{2} \mathrm{O}$ and $\mathrm{ZrO}\left(\mathrm{NO}_{3}\right)_{2} \cdot 7 \mathrm{H}_{2} \mathrm{O}$ solution in ammonia, followed by calcination in air at $700{ }^{\circ} \mathrm{C}$. This composition was chosen in light of previous studies on various ceria-zirconia mixed oxides, which showed that this solid exhibited the best oxygen storage capacity, catalytic properties and thermal stability after ageing at high temperature [11]. Pt (2wt.\%) was introduced by wet impregnation of a $\left.\left[\mathrm{Pt}\left(\mathrm{NH}_{3}\right)_{4}\right]\left(\mathrm{NO}_{3}\right)_{2}\right]$ solution. The catalyst was calcined at $400{ }^{\circ} \mathrm{C}$ in $\mathrm{O}_{2}$, then reduced in $\mathrm{H}_{2}$ at $300{ }^{\circ} \mathrm{C}$.

Catalytic activity measurements are performed at atmospheric pressure, in the presence of $\approx 1$ vol.\% isooctane, chosen as model compound for gasoline, diluted in argon. Liquid flow controllers are used to adjust the isooctane and water feeds, which are vaporized separately, then mixed with the gaseous components. The reformate composition is analysed with a micro gas chromatograph (Agilent) equipped with three analytic modules (molecular sieve and Poraplot U columns with backflush, OV1 column without backflush) allowing complete analysis in $160 \mathrm{~s}$. A mass spectrometer (Inficon) is also used for a continuous monitoring of the reaction. The typical feed gas is composed of $1 \mathrm{vol} \%$ isooctane, $1 \mathrm{vol} . \% \mathrm{~N}_{2}$ as internal standard, variable $\mathrm{O}_{2}$ and $\mathrm{H}_{2} \mathrm{O}(\%)$, balance argon. The gas hourly space velocity (GHSV) is set to $150000 \mathrm{~h}^{-1}$. Water could not be analysed accurately during the reaction, because its analysis by chromatography and mass spectrometry was not reliable, while it is at the same time a reactant and a reaction product. A satisfactory hydrogen balance could nevertheless be assessed by comparing the isooctane and steam amounts at the reactor inlet (known accurately) with all analyzed hydrogen-containing compounds at the outlet, referred to nitrogen introduced as internal standard.

The specific surface areas were measured by nitrogen adsorption at $77 \mathrm{~K}$ using the multipoint method. The samples were previously treated at $673 \mathrm{~K}$ under vacuum $\left(2 \times 10^{-3} \mathrm{~Pa}\right)$ for $2 \mathrm{~h}$. Powder $\mathrm{X}$-ray diffraction patterns were recorded with a Bruker D5005 diffractometer using monochromatised $\mathrm{Cu} K \alpha$ radiation. The patterns were recorded between $3^{\circ}$ and $80^{\circ}(2 \theta)$, with a scan rate of $1.2^{\circ} \mathrm{min}^{-1}$. SEM images were obtained with a Hitachi S800 electron microscope operating at $15 \mathrm{kV}$. TPO experiments were performed on the setup used for catalytic activity measurements, using both the micro-chromatograph (one analysis every $90 \mathrm{~s}$ ) and the calibrated mass spectrometer to quantify the consumption of oxygen and the formation of carbon oxides. The total flow was $28 \mathrm{~mL} / \mathrm{min}$.

The HSC-Chemistry version 4.0 software (OUTOKUMPU, Finland) was used to calculate the equilibrium composition. These thermodynamic calculations are based on the minimisation of the free Gibbs energy.

\section{Results and discussion}

The combined reforming of isooctane involves a complex set of chemical reactions, in which primary reactions lead to the decomposition of the hydrocarbon, while many secondary reactions may also take place between the different products together and with steam. 
Total oxidation:

$$
\begin{gathered}
\mathrm{C}_{8} \mathrm{H}_{18}+\frac{25}{2} \mathrm{O}_{2} \rightarrow 8 \mathrm{CO}_{2}+9 \mathrm{H}_{2} \mathrm{O} \\
\left(\Delta H_{298}^{\circ}=-5065 \mathrm{~kJ} \mathrm{~mol}^{-1}\right)
\end{gathered}
$$

Partial oxidation:

$$
\begin{array}{r}
\mathrm{C}_{8} \mathrm{H}_{18}+4 \mathrm{O}_{2} \rightarrow 8 \mathrm{CO}+9 \mathrm{H}_{2} \\
\left(\Delta H_{298}^{\circ}=-625 \mathrm{~kJ} \mathrm{~mol}^{-1}\right)
\end{array}
$$

Steam reforming:

$$
\begin{gathered}
\mathrm{C}_{8} \mathrm{H}_{18}+8 \mathrm{H}_{2} \mathrm{O} \rightarrow 8 \mathrm{CO}+17 \mathrm{H}_{2} \\
\left(\Delta H_{298}^{\circ}=1310 \mathrm{~kJ} \mathrm{~mol}^{-1}\right)
\end{gathered}
$$

Cracking:

$$
\mathrm{C}_{8} \mathrm{H}_{18} \rightarrow 8 \mathrm{C}+9 \mathrm{H}_{2} \quad\left(\Delta H_{298}^{\circ}=391 \mathrm{~kJ} \mathrm{~mol}^{-1}\right)
$$

$\mathrm{CO}_{2}$ reforming:

$$
\begin{gathered}
\mathrm{C}_{8} \mathrm{H}_{18}+8 \mathrm{CO}_{2} \rightarrow 16 \mathrm{CO}+9 \mathrm{H}_{2} \\
\left(\Delta H_{298}^{\circ}=1639 \mathrm{~kJ} \mathrm{~mol}^{-1}\right)
\end{gathered}
$$

Water-gas shift:

$$
\mathrm{CO}+\mathrm{H}_{2} \mathrm{O} \rightleftarrows \mathrm{CO}_{2}+\mathrm{H}_{2} \quad\left(\Delta H_{298}^{\circ}=-41 \mathrm{~kJ} \mathrm{~mol}^{-1}\right)
$$

Methanation:

$$
\begin{aligned}
& \mathrm{CO}+3 \mathrm{H}_{2} \rightleftarrows \mathrm{CH}_{4}+\mathrm{H}_{2} \mathrm{O} \\
&\left(\Delta H_{298}^{\circ}=-206 \mathrm{~kJ} \mathrm{~mol}^{-1}\right) \\
& \mathrm{CO}_{2}+4 \mathrm{H}_{2} \rightleftarrows \mathrm{CH}_{4}+2 \mathrm{H}_{2} \mathrm{O} \\
& \quad\left(\Delta H_{298}^{\circ}\right.\left.=-165 \mathrm{~kJ} \mathrm{~mol}^{-1}\right) \\
& \mathrm{C}+2 \mathrm{H}_{2} \rightleftarrows \mathrm{CH}_{4} \quad\left(\Delta H_{298}^{\circ}=-75 \mathrm{~kJ} \mathrm{~mol}^{-1}\right)
\end{aligned}
$$

Boudouard:

$$
2 \mathrm{CO} \rightleftarrows \mathrm{C}+\mathrm{CO}_{2} \quad\left(\Delta H_{298}^{\circ}=-172 \mathrm{~kJ} \mathrm{~mol}^{-1}\right)
$$

Carbon gasification:

$$
\mathrm{C}+\mathrm{H}_{2} \mathrm{O} \rightleftarrows \mathrm{CO}+\mathrm{H}_{2} \quad\left(\Delta H_{298}^{\circ}=131 \mathrm{~kJ} \mathrm{~mol}^{-1}\right)
$$

The main catalytic reactions involved in ATR for hydrogen production are partial and total oxidation, steam reforming (SR) and WGS. Total and partial oxidation reactions are exothermic, whereas steam reforming is highly endothermic. The WGS is slightly exothermic. Therefore, the relative amounts of oxygen (oxygen to carbon, $\mathrm{O} / \mathrm{C}$ ratio) and steam (steam-to-carbon, $\mathrm{H}_{2} \mathrm{O} / \mathrm{C}$ ratio) reacted with isooctane will determine the overall reactions pathways and the hydrogen productivity.

\subsection{Thermodynamic study: conditions for the thermoneutrality of isooctane ATR}

The variation of the heat of reaction, upon reacting isooctane with various amounts of oxygen and steam, is represented in Fig. 1. As expected, the O/C ratio has a very strong effect on the heat of reaction, the thermoneutrality being obtained with an $\mathrm{O} / \mathrm{C}$ ratio around unity. The steam

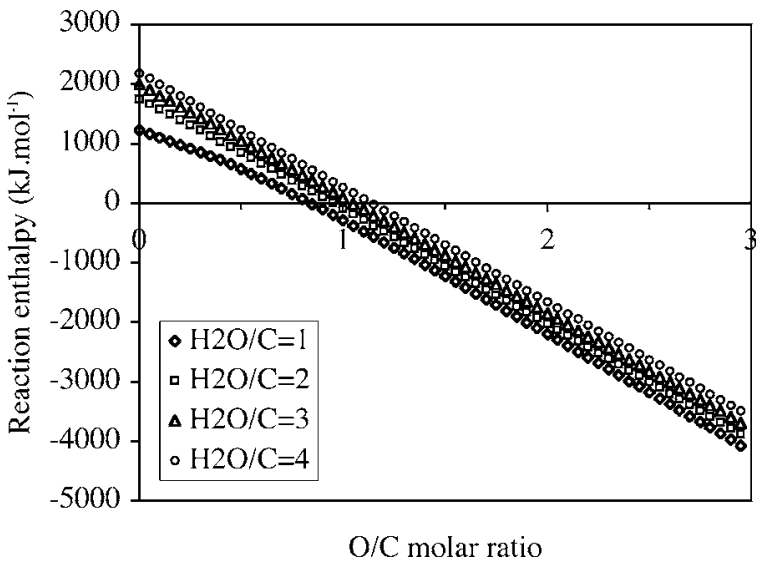

Fig. 1. Variation of reaction enthalpy upon reacting isooctane with various amounts of oxygen and steam (temperature: $680^{\circ} \mathrm{C}$.).

content has only a moderate impact on the reaction enthalpy, which is not surprising since $\mathrm{H}_{2} \mathrm{O} / \mathrm{C}=1$ already represents the stoichiometric ratio for steam reforming. Therefore, the extra water should only affect the WGS equilibrium.

Based on the work of Hagh [12,13], who investigated the efficiency of the autothermal reforming process for various fuels, we used a simulation based on energy and components balance to calculate the maximum hydrogen yield that can be obtained by ATR of isooctane.

The ATR of hydrocarbons is sometimes strictly defined as the combination of partial oxidation (PO, Eq. (2)) and steam reforming (SR, Eq. (3)), in which the exothermic PO reaction provides the heat necessary for the endothermic SR, leading to thermoneutral balance $\left(\Delta H_{\mathrm{r}}=0\right)$. However, because of the parallel reactions described above, the stoichiometry of isooctane ATR is best described [12] as

$\mathrm{C}_{8} \mathrm{H}_{18}+x \mathrm{O}_{2}+y \mathrm{H}_{2} \mathrm{O} \Rightarrow a \mathrm{CH}_{4}+b \mathrm{CO}+c \mathrm{CO}_{2}+d \mathrm{H}_{2}$

where $x=\mathrm{O}_{2 \text { reacted }} / \mathrm{C}_{8} \mathrm{H}_{18 \text { reformed }}, \quad y=\mathrm{H}_{2} \mathrm{O}_{\text {reacted }} / \mathrm{C}_{8} \mathrm{H}_{18 \text { re- }}$ formed, $a=\mathrm{CH} 4$ produced $/ \mathrm{C}_{8} \mathrm{H}_{18 \text { reformed }}, b=\mathrm{CO}_{\text {produced }} / \mathrm{C}_{8} \mathrm{H}_{18 \mathrm{re}-}$ formed, $\quad c=\mathrm{CO} 2$ produced $/ \mathrm{C}_{8} \mathrm{H}_{18 \text { reformed }}$ and $d=\mathrm{H}_{2 \text { produced }} /$ $\mathrm{C}_{8} \mathrm{H}_{18 \text { reformed. }}$.

The following equations represent the atomic balances for $\mathrm{O}, \mathrm{C}$ and $\mathrm{H}$ in Eq. (12), respectively:

$2 x+y=b+2 c$

$a+b+c=8$

$2 y+18=4 a+2 d$

By combining these three equations and rearranging, the hydrogen yield can be expressed as

$d=25-2 x-(b+4 a)$

Eq. (12) assumes that there is no significant carbon deposition as a main product. The maximum theoretical hydrogen yield is actually obtained when $\mathrm{CO}_{2}$ is the only carbonaceous product. In this case, Eq. (16) reduces to

$d_{\text {max }}=25-2 x$ 
Dividing Eq. (17) by 25 , a normalized yield of $\mathrm{H}_{2}$ can be defined as

$d_{n \max }=1-R$

where the stoichiometric ratio $R$ is the ratio between the oxygen reacted in ATR and the stoichiometric oxygen required for total combustion:

$R=\frac{2 x}{25}$

In the ATR of isooctane (Eq. (12)), the $\mathrm{O} / \mathrm{C}$ ratio used in the feed gas is defined by

$\mathrm{O} / \mathrm{C}=\frac{2 x}{8}$

Therefore, the stoichiometric ratio $R$ can be expressed as a function of the $\mathrm{O} / \mathrm{C}$ ratio by

$R=\frac{8}{25} \mathrm{O} / \mathrm{C}$

Combining Eqs. (18) and (21) leads to

$d_{n \max }=\frac{1-8}{25} \mathrm{O} / \mathrm{C}$

Under endothermic reaction conditions, additional heat must be provided by external fuel combustion to provide the required energy for the reaction. Thus, the approach based on material balance overestimates the hydrogen yield, which must be expressed as

$d_{n}=\frac{\mathrm{H}_{2 \text { produced }}}{25\left(\mathrm{C}_{8} \mathrm{H}_{18 \text { reformed }}+\mathrm{C}_{8} \mathrm{H}_{18 \text { burnt }}\right)}$

Fig. 2 displays the evolution of the maximum normalised $\mathrm{H}_{2}$ yield as a function of the $\mathrm{O} / \mathrm{C}$ molar ratio, at various $\mathrm{H}_{2} \mathrm{O} / \mathrm{C}$ ratios. At $\mathrm{H}_{2} \mathrm{O} / \mathrm{C}=1$, the $\mathrm{H}_{2}$ yield is clearly highest with an $\mathrm{O} / \mathrm{C}$ ratio close to unity. This maximum still exists at $\mathrm{H}_{2} \mathrm{O} /$ $\mathrm{C}=2$, although less marked. At higher $\mathrm{H}_{2} \mathrm{O} / \mathrm{C}$ ratios ( 3 and 4), the $\mathrm{H}_{2}$ yield is slightly higher for pure steam reforming processes. There is, however, a clear change in the slope of the curves around $\mathrm{O} / \mathrm{C}=1$, the hydrogen yield decreasing steeply at $\mathrm{O} / \mathrm{C}$ ratios $>1$. Noteworthy is the strong impact of

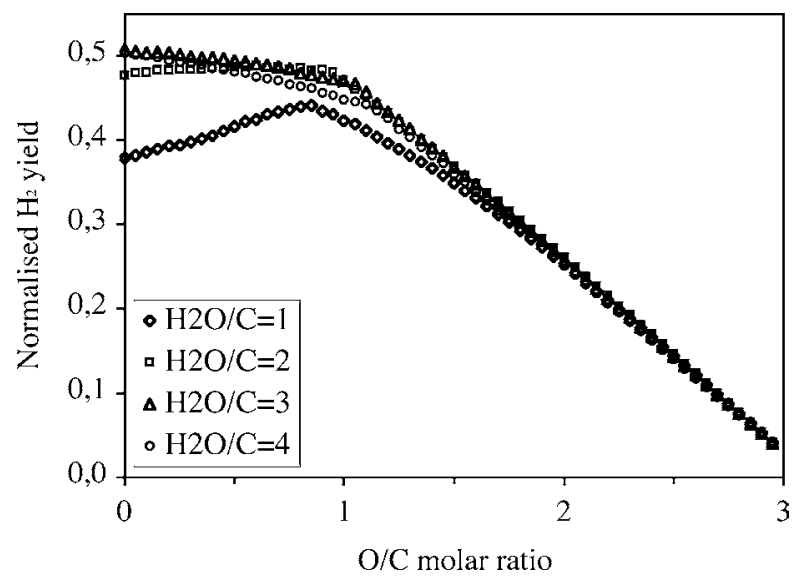

Fig. 2. Evolution of the normalised maximum $\mathrm{H}_{2}$ yield with $\mathrm{O} / \mathrm{C}$ ratio, at various $\mathrm{H}_{2} \mathrm{O} / \mathrm{C}$ ratios (conditions: $680{ }^{\circ} \mathrm{C}, 1 \mathrm{~atm}$ ). changing the $\mathrm{H}_{2} \mathrm{O} / \mathrm{C}$ ratio from 1 to 2 on the production of hydrogen, whereas higher steam amounts virtually do not modify it.

Therefore, the conditions for the thermal neutrality $\left(\Delta H_{\mathrm{r}}=0\right.$ at $\mathrm{O} / \mathrm{C}$ close to 1$)$ shown in Fig. 1 also correspond to the maximum hydrogen yield, at $\mathrm{H}_{2} \mathrm{O} / \mathrm{C}<3$. This is consistent with other calculations on the ATR of various fuels [14], which concluded that the reforming process is the most efficient when the reaction is heat balanced.

\subsection{Catalytic activity under optimised gas feed composition}

The Pt/ceria-zirconia catalyst was tested in the reforming of isooctane under the gas feed composition previously determined as optimum by calculations $\left(\mathrm{O} / \mathrm{C}=1, \mathrm{H}_{2} \mathrm{O} /\right.$ $\mathrm{C}=2$ ). The test includes first a temperature-programmed reaction between 350 and $730{ }^{\circ} \mathrm{C}$, in order to determine the light-off temperature for hydrogen production, followed by several dwells at different temperatures to check the catalyst stability under isothermal conditions.

Fig. 3 discloses the reformate composition and the conversion of isooctane at the reactor outlet, as a function of time and temperature. The composition is given in percentage of the "dry" reformate, which takes into account all the gaseous products formed (except water), but also unconverted isooctane, when the conversion is not total.

At the beginning of the temperature ramp $\left(350{ }^{\circ} \mathrm{C}\right)$, oxygen is already completely consumed, $\mathrm{CO}_{2}$ being the only product. The conversion of isooctane is around 35\%, which corresponds to the amount of oxygen available in the gas feed. During the ramp, $\mathrm{CO}_{2}$ remains the only product until the temperature reaches $600{ }^{\circ} \mathrm{C}$ (i.e. between 0 and $2 \mathrm{~h}$ time on stream). Hydrogen starts to form above $600{ }^{\circ} \mathrm{C}$, its level increasing regularly to become the main component above $650{ }^{\circ} \mathrm{C}$. $\mathrm{CO}$ is formed only together with $\mathrm{H}_{2}$. Total conversion of isooctane is reached at $710^{\circ} \mathrm{C}$.

At the end of this ramp, the catalyst was tested under isothermal conditions at different temperatures $(730,535$, $584,633,683,730$ then back to $584{ }^{\circ} \mathrm{C}$, corresponding to the $3.7-15.5 \mathrm{~h}$ time scale). During the first dwell at $730{ }^{\circ} \mathrm{C}$ (time scale 3.6-4.6 h), the conversion of isooctane is total and the percentage of hydrogen in the reformate reaches $62 \%$. Upon decreasing the temperature to $535{ }^{\circ} \mathrm{C}$ (time scale: $5 \mathrm{~h}-$ $5 \mathrm{~h} 40 \mathrm{~min}$ ), the conversion of isooctane shows a sharp fall to about $47 \%$, the production of hydrogen stops whereas again only total combustion of isooctane takes place. Upon increasing the temperature, increasing amounts of hydrogen and $\mathrm{CO}$ are formed, while the percentage of $\mathrm{CO}_{2}$ decreases symmetrically. The catalytic activity is stable under isothermal conditions. It is important to note that the activity during the final dwell at $584^{\circ} \mathrm{C}$ (time scale: $15 \mathrm{~h}-$ $15 \mathrm{~h} 30 \mathrm{~min}$ ) is identical to that obtained within the first dwell at this temperature (time scale: $6-8 \mathrm{~h}$ ), indicating that the catalyst remains quite stable after having been submitted to various reaction temperatures. 


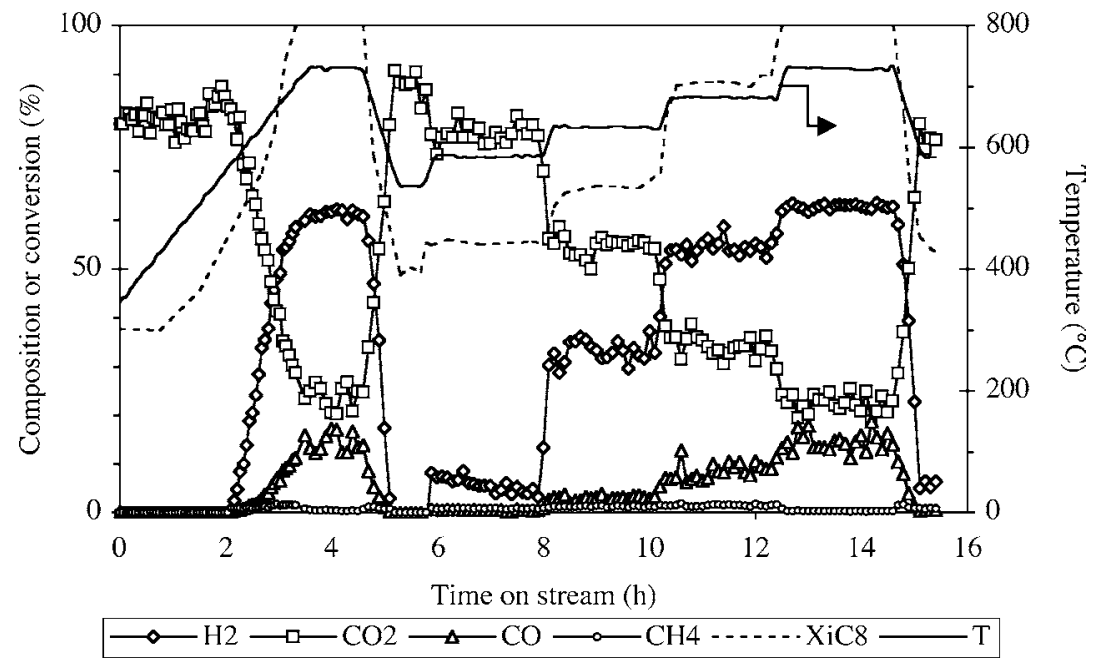

Fig. 3. Catalytic activity under temperature ramp and dwells (conditions: 1 vol. $\%$ isooctane, $\mathrm{O} / \mathrm{C}=1, \mathrm{H}_{2} \mathrm{O} / \mathrm{C}=2, \mathrm{SV}=150000 \mathrm{~h}^{-1}$ ).

\subsection{Effect of the $\mathrm{O} / \mathrm{C}$ ratio}

As previously demonstrated (Section 3.1), the $\mathrm{O} / \mathrm{C}$ ratio is a critical parameter for ATR. Fig. 4 displays the influence of this ratio on the reformate composition, and on isooctane conversion, at $680^{\circ} \mathrm{C}$. This temperature was chosen in order to have a sufficient hydrogen yield, but incomplete conversion of isooctane, so that variations in the conversion of isooctane can be observed. The $\mathrm{O} / \mathrm{C}$ ratio is varied from 0 (pure steam reforming) to 1.5 , whereas the $\mathrm{H}_{2} \mathrm{O} / \mathrm{C}$ ratio is set at 1.5 .

Addition of oxygen in the feed gas strongly improves the conversion of isooctane: when the $\mathrm{O} / \mathrm{C}$ ratio is increased from 0 to 1.5, the conversion increases from 60 to $90 \%$. The amount of $\mathrm{CO}_{2}$ formed follows the same trend (Fig. 4). At any of the $\mathrm{O} / \mathrm{C}$ ratios, oxygen is completely converted. Increasing the amount of oxygen in the feed gas clearly favours the total oxidation of isooctane. However, the hydrogen production also increases with $\mathrm{O} / \mathrm{C}$ up to 0.75 , and

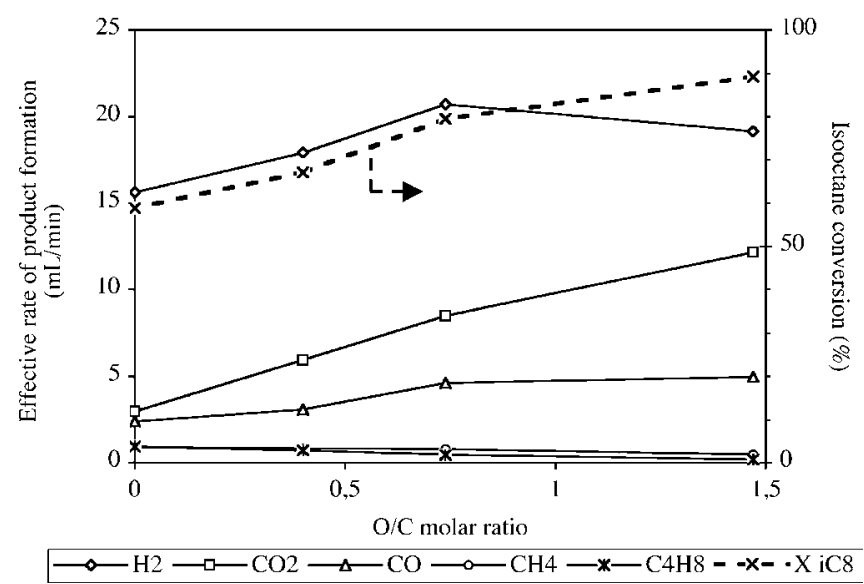

Fig. 4. Isooctane conversion and products distribution as a function of $\mathrm{O} / \mathrm{C}$ ratio (conditions: $680{ }^{\circ} \mathrm{C}, 1.3 \mathrm{vol} \%$ isooctane, variable $\mathrm{O}_{2}, \mathrm{H}_{2} \mathrm{O} / \mathrm{C}=1.5$, balance Ar). then decreases at $\mathrm{O} / \mathrm{C}=1.5$. This suggests that the introduction of oxygen does not only lead to isooctane combustion, but also modifies the products selectivity by changing the relative influence of the reactions involved. At a too high $\mathrm{O} / \mathrm{C}$ ratio, however, the combustion of isooctane becomes detrimental to the hydrogen production.

It should be mentioned that, in the absence of oxygen, the catalyst deactivates with time on stream: the production of hydrogen falls from 22.7 to $15.3 \mathrm{~mL} / \mathrm{min}$ in $2 \mathrm{~h}$. The carbon balance is also lower than 1 in this case (in the 0.93-0.95 range), which is indicative of carbon deposition on the catalyst. In contrast, there is no deactivation when oxygen is present in the gas feed, and the carbon balance remains very close to 1 .

The hydrogen concentration (Fig. 4) is much lower, at low $\mathrm{O} / \mathrm{C}$ ratios, than the calculated equilibrium composition, shown on Fig. 5 (e.g. $20.7 \mathrm{~mL} / \mathrm{min}_{2}$ are produced at $\mathrm{O} /$ $\mathrm{C}=0.74$ whereas 36.8 should be expected). This clearly indicates that the reaction is not at equilibrium under our

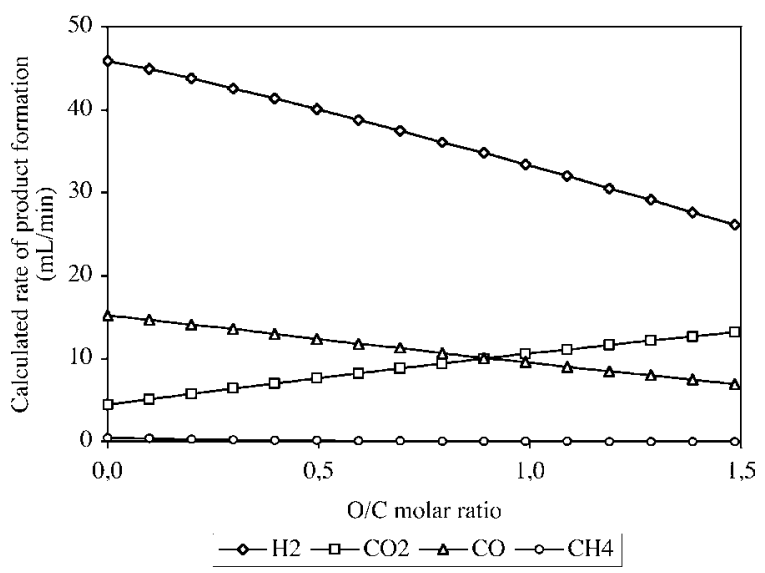

Fig. 5. Calculated equilibrium composition at $680^{\circ} \mathrm{C}$ (conditions: 1.3 vol. \% isooctane, variable $\mathrm{O}_{2}, \mathrm{H}_{2} \mathrm{O} / \mathrm{C}=1.5$, balance $\mathrm{Ar}$ ). Isooctane is totally converted. 
experimental conditions (the equilibrium conversion of isooctane is $100 \%$ at this temperature, whatever the $\mathrm{O} / \mathrm{C}$ ratio). At $\mathrm{O} / \mathrm{C}=1.5$, the isooctane conversion reaches $90 \%$, and the rate of hydrogen production $(19.2 \mathrm{~mL} / \mathrm{min})$ is then the closest to its equilibrium value $(26.1 \mathrm{~mL} / \mathrm{min})$.

$\mathrm{CO}_{2}$ is always formed in higher amounts than $\mathrm{CO}$, while the thermodynamics predict the opposite for $\mathrm{O} / \mathrm{C}<0.9$. This high $\mathrm{CO}_{2}$ content reveals that, in the presence of oxygen and when the reaction is kinetically controlled, the total oxidation of isooctane is favoured compared to steam reforming. Total oxidation is indeed much faster. In the absence of oxygen, where the reactions (SR of isooctane and WGS) are expected to form much more $\mathrm{CO}$ than $\mathrm{CO}_{2}$ (Fig. 5), the experimental data also reveal a $\mathrm{CO}_{2}$ level slightly higher than $\mathrm{CO}$ (Fig. 4). However, at any of the inlet $\mathrm{O} / \mathrm{C}$ ratios, the outlet composition in $\mathrm{CO}, \mathrm{H}_{2}, \mathrm{CO}_{2}$ and $\mathrm{H}_{2} \mathrm{O}$ fits the WGS equilibrium, which means that only the reactions involving isooctane are not equilibrated.

Methane and 2-butene are formed in low levels at any of the $\mathrm{O} / \mathrm{C}$ ratios, their concentration decreasing when the oxygen content in the feed increases. Methane cannot be formed through the secondary reactions of $\mathrm{CO}$ or $\mathrm{CO}_{2}$ methanation at $680{ }^{\circ} \mathrm{C}$ since the thermodynamics of these two reactions are not favourable at high temperature $\left(\Delta G>0\right.$ between 650 and $\left.800^{\circ} \mathrm{C}\right)$. Recent kinetic experiments [6] on the ATR of isooctane also excluded the methanation of $\mathrm{CO}$ and $\mathrm{CO}_{2}$ from the methane formation pathway. Therefore, a more complex cracking scheme of isooctane into lower hydrocarbons has to be considered to account for the formation of these products, rather than the over-simplified Eq. (4) initially proposed. More precisely, the cracking of isooctane can be expected to take place in the downstream reactor zone, where no more oxygen is present.

The opposite effect of the $\mathrm{O} / \mathrm{C}$ ratio on the conversion of isooctane and on the $\mathrm{H}_{2}+\mathrm{CO}$ selectivity is illustrated in Fig. 6: the increase in isooctane conversion obtained while increasing $\mathrm{O}_{2}$ concentration in the feed is always at the expense of the $\mathrm{H}_{2}+\mathrm{CO}$ selectivity. Therefore, an $\mathrm{O} / \mathrm{C}$ ratio between 0.5 and 1 clearly appears as the best compromise between activity and selectivity in the desired products

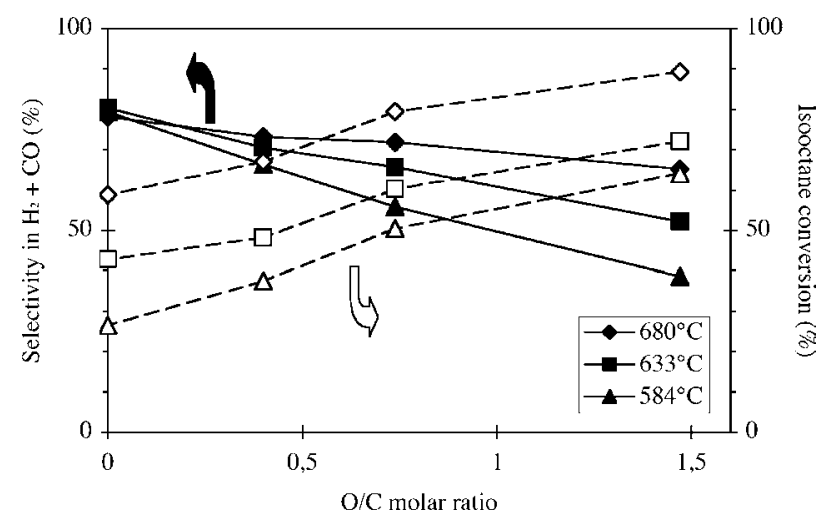

Fig. 6. Evolution of isooctane conversion (open symbols) and selectivity in $\mathrm{H}_{2}+\mathrm{CO}$ (filled symbols) as a function of $\mathrm{O} / \mathrm{C}$ ratio at different reaction temperatures.
$\left(\mathrm{H}_{2}+\mathrm{CO}\right)$. With $\mathrm{O} / \mathrm{C}=0.75$, the conversion of isooctane is complete at $750{ }^{\circ} \mathrm{C}$.

The calculations presented in Section 3.1 predicted that the reaction performed at $\mathrm{H}_{2} \mathrm{O} / \mathrm{C}=2$ should be thermoneutral at an $\mathrm{O} / \mathrm{C}$ ratio of 0.95 . Under our experimental conditions, an $\mathrm{O} / \mathrm{C}$ ratio of 0.75 corresponds to an optimum hydrogen production (Fig. 4). This ratio, however, was not determined accurately, while the conversion of isooctane was not total and varied with the $\mathrm{O} / \mathrm{C}$ ratio. It is nevertheless interesting to compare our experimental data to the more complex Ahmed and Krumpelt's calculations [14] on the reforming of various fuels, including isooctane, which took into account the process efficiency: the conditions calculated for thermoneutrality were $\mathrm{O}_{2} / \mathrm{C}_{8} \mathrm{H}_{18}=2.947$ (or $\mathrm{O} / \mathrm{C}=0.737$ ), which also correspond to the maximum efficiency of the process. This corresponds well to the optimum of activity we observe.

\subsection{Effect of the $\mathrm{H}_{2} \mathrm{O} / \mathrm{C}$ ratio}

Fig. 7 depicts the variation in the composition of the dry reformate and the conversion of isooctane, at $680{ }^{\circ} \mathrm{C}$, as a function of the $\mathrm{H}_{2} \mathrm{O} / \mathrm{C}$ ratio. In these measurements, the $\mathrm{H}_{2} \mathrm{O} / \mathrm{C}$ molar ratio was varied between 0 and 2.4, while the molar $\mathrm{O} / \mathrm{C}$ ratio was kept equal to 0.8 .

In the absence of steam, the catalyst undergoes rapid deactivation: the rate of hydrogen production falls from 9.7 to $2.2 \mathrm{~mL} / \mathrm{min}$ in $2 \mathrm{~h}$. The presence of steam in the feed gas gives a much more stable activity, although at $\mathrm{H}_{2} \mathrm{O} / \mathrm{C}=0.8$ a slight deactivation is still observed. The conversion of isooctane and the hydrogen production are strongly improved as soon as steam is added in the feed gas: at $\mathrm{H}_{2} \mathrm{O} / \mathrm{C}=0.8$, the production of hydrogen is roughly tripled. The stoichiometric ratio for the SR of isooctane corresponds to $\mathrm{H}_{2} \mathrm{O} / \mathrm{C}=1$ (Eq. (3)). Increasing the level of steam above this stoichiometry further improves the production of hydrogen. However, the $\mathrm{CO}$ level remains roughly constant with increasing steam content, whereas $\mathrm{CO}_{2}$ increases

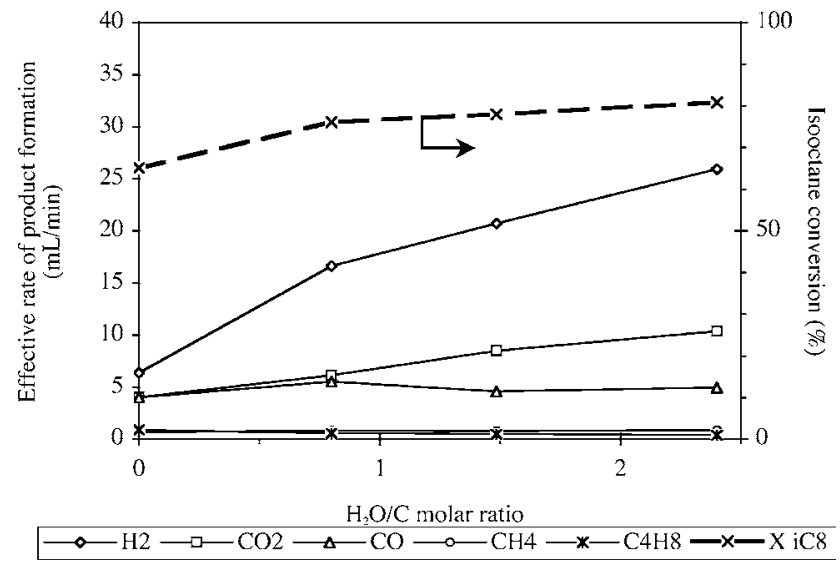

Fig. 7. Influence of the $\mathrm{H}_{2} \mathrm{O} / \mathrm{C}$ ratio on the reformate composition and on isooctane conversion (conditions: $680{ }^{\circ} \mathrm{C}, 1.3$ vol.\% isooctane, $\mathrm{O} / \mathrm{C}=0.8$, variable $\mathrm{H}_{2} \mathrm{O}, \mathrm{SV}=150000 \mathrm{~h}^{-1}$ ). 


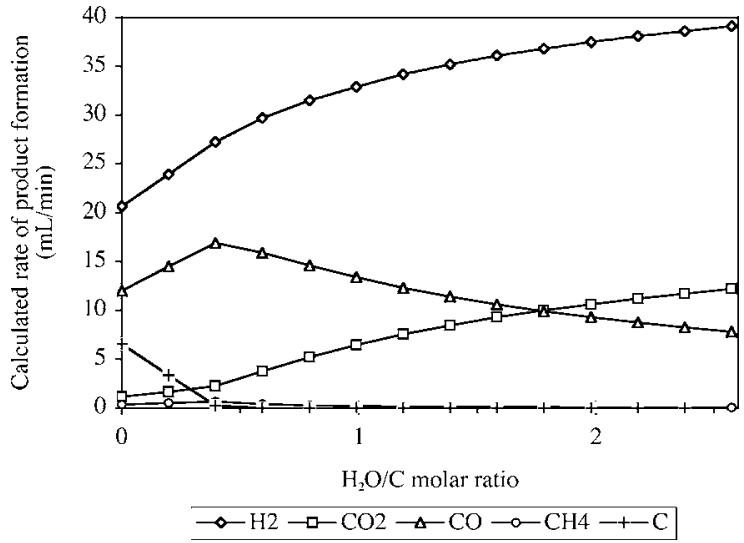

Fig. 8. Calculated equilibrium composition of the reformate at different $\mathrm{H}_{2} \mathrm{O} / \mathrm{C}$ ratios (conditions: $680{ }^{\circ} \mathrm{C}, 1.3$ vol. $\%$ isooctane, $\mathrm{O} / \mathrm{C}=0.8$, balance $\mathrm{Ar})$.

together with $\mathrm{H}_{2}$. This is in good agreement with the displacement of the WGS equilibrium with the steam content towards the formation of $\mathrm{H}_{2}$ and $\mathrm{CO}_{2}$.

Our experiments show a monotonous increase in $\mathrm{H}_{2}$ production up to $\mathrm{H}_{2} \mathrm{O} / \mathrm{C}=2.4$, whereas the calculations have shown previously (Fig. 2) that increasing the $\mathrm{H}_{2} \mathrm{O} / \mathrm{C}$ ratio above 2 should only have a minimal impact on the production of hydrogen. Our test bench did not allow us to test the catalyst in the presence of higher steam amounts: the vaporisation of water becomes critical at high steam levels, leading to unstable steam flows. However, the difference between experiments and calculations can be ascribed to the fact that the reaction is not at equilibrium under our experimental conditions (high space velocity), the conversion of isooctane being not total. Therefore, only the WGS reaction is at equilibrium, and is directly influenced by the steam content.

As already observed previously, the production of hydrogen is much lower than predicted at the thermodynamic equilibrium (Figs. 8 and 9), due to incomplete

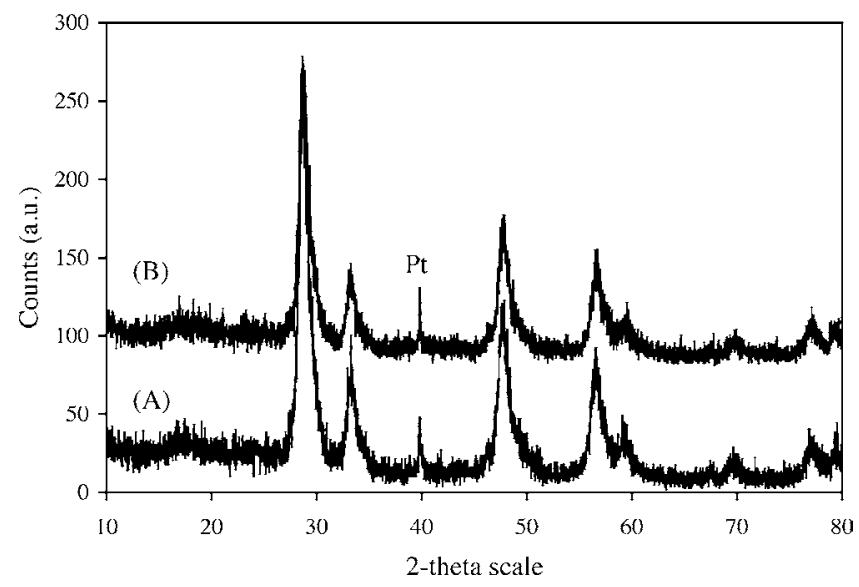

Fig. 9. X-ray diffraction patterns of fresh and used Pt/ceria-zirconia catalyst. conversion of isooctane. Carbon deposition is also predicted at low $\mathrm{H}_{2} \mathrm{O} / \mathrm{C}$ ratios.

In conclusion, increasing the steam-to-carbon ratio is clearly beneficial in terms of hydrogen productivity. The steam content, however, does not strongly affect the conversion of isooctane, but rather the WGS equilibrium. Moreover, the heat of vaporisation of water was not taken into account in our experiments, since it is vaporised independently from the reactor. This also increases the energy cost, and the choice of a $\mathrm{H}_{2} \mathrm{O} / \mathrm{C}$ ratio will require a compromise between the amount of $\mathrm{H}_{2}$ produced and the energy required to produce it.

\subsection{Characterization of fresh and used Pt/ceria-zirconia catalyst}

The specific surface area of the fresh catalyst, prepared by impregnation of the ceria-zirconia support previously calcined at $700{ }^{\circ} \mathrm{C}$, is $70 \mathrm{~m}^{2} \mathrm{~g}^{-1}$. After catalytic tests, during which the catalyst was repeatedly exposed to temperatures up to $730{ }^{\circ} \mathrm{C}$, the surface area decreased to $49 \mathrm{~m}^{2} \mathrm{~g}^{-1}$. Rather than the modest increase in temperature $\left(+30^{\circ} \mathrm{C}\right)$ compared to the initial calcination temperature of the ceria-zirconia support, this sintering is probably related to the high amount of steam present in the feed gas during the activity measurements. Steam is well known for its promoting effect on the sintering of oxides: in the case of an alumina support [15], this effect could be related to a mechanism in which the rate-determining step of the sintering process is the surface diffusion of hydroxyl ions.

The X-ray diffraction pattern of the fresh catalyst presents the diffraction lines of cubic ceria, slightly displaced towards larger angles due to $\mathrm{Zr}^{4+}$ (smaller than $\mathrm{Ce}^{4+}$ ) incorporation in the ceria structure. The main diffraction line of $\mathrm{Pt}$ is also visible, although weak, since only some large Pt particles diffract. After reaction, the diffractogram is virtually unmodified: the diffraction lines of the ceria-zirconia support are only slightly thinner, in agreement with the loss of surface area. The integral breadth of the $100 \%$ peak of $\mathrm{Pt}$ is also thinner, which suggests the sintering of platinum. In the fresh catalyst, the platinum has been simply treated at $400{ }^{\circ} \mathrm{C}$ to decompose the Pt salt. The reaction conditions also lead to the sintering of platinum, as also observed for nickel-based catalysts under steam reforming conditions [16]. Recently, the effect of steam on the sintering of Ni catalysts has also been related to the formation of Ni-bonded hydroxyl groups [17]. In our case however, the catalytic activity of the Pt catalyst exhibits a good stability after the first temperature ramp up to $730{ }^{\circ} \mathrm{C}$, suggesting that this sintering takes place rapidly during this ramp. Therefore, the catalyst is quickly stabilized under reaction conditions.

SEM examination of the fresh catalyst (Fig. 10A) shows small, roughly spherical crystallites of ceria-zirconia support with sizes around $25-30 \mathrm{~nm}$. The aspect of the spent catalyst is identical (Fig. 10B), and there is no clear increase in the support crystallite size, except that less small 


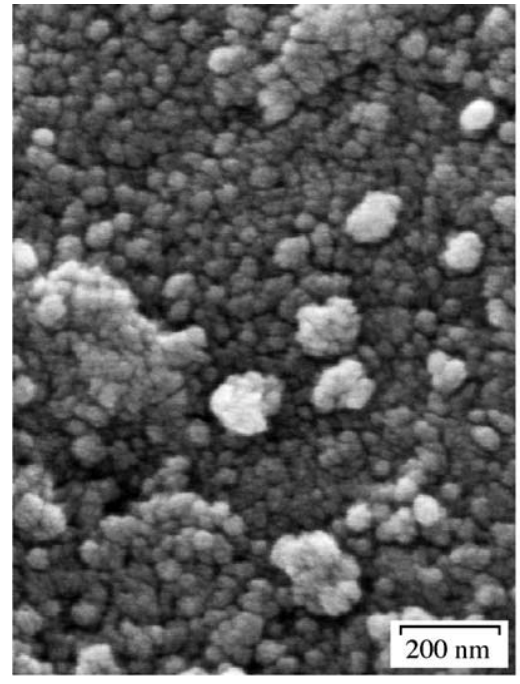

(A)

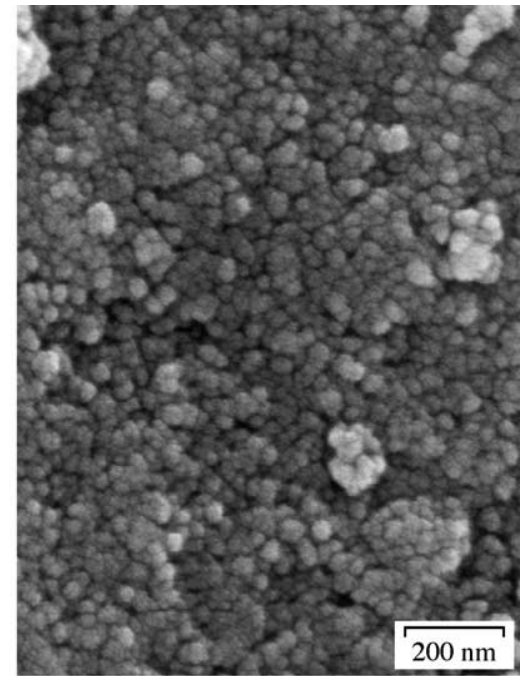

(B)

Fig. 10. SEM images of fresh (A) and used (B) $\mathrm{Pt} / \mathrm{CeO}_{2}-\mathrm{ZrO}_{2}$ catalyst.

crystallites are present, and that some crystallites with sizes up to $40 \mathrm{~nm}$ can be noticed. No carbon whiskers are observed, as could be seen on other catalysts (i.e. $\mathrm{Ru} / \mathrm{Al}_{2} \mathrm{O}_{3}$ ) tested under the same reaction conditions. On the only basis of the SEM characterization, it is of course not possible to exclude the formation of encapsulating carbon, but this carbon should lead to the deactivation of the catalyst, which is generally not observed.

Certain reaction conditions, however, did cause a time-onstream deactivation of the $\mathrm{Pt} /$ ceria-zirconia catalyst. In particular, the catalyst was found to deactivate under pure partial oxidation conditions, when no steam is added to the feed (Section 3.4). The catalyst was tested under $\mathrm{O} / \mathrm{C}=1$ and $\mathrm{H}_{2} \mathrm{O} / \mathrm{C}=0$, at three different temperatures $(584,633$ and $680{ }^{\circ} \mathrm{C}, 2 \mathrm{~h}$ at each temperature). At $680^{\circ} \mathrm{C}$, the isooctane conversion falls from 69 to $60 \%$ in $2 \mathrm{~h}$. In order to quantify the carbon deposition, the catalyst was subsequently submitted to a temperature-programmed oxidation under diluted oxygen. The corresponding oxidation profile is displayed in Fig. 11.

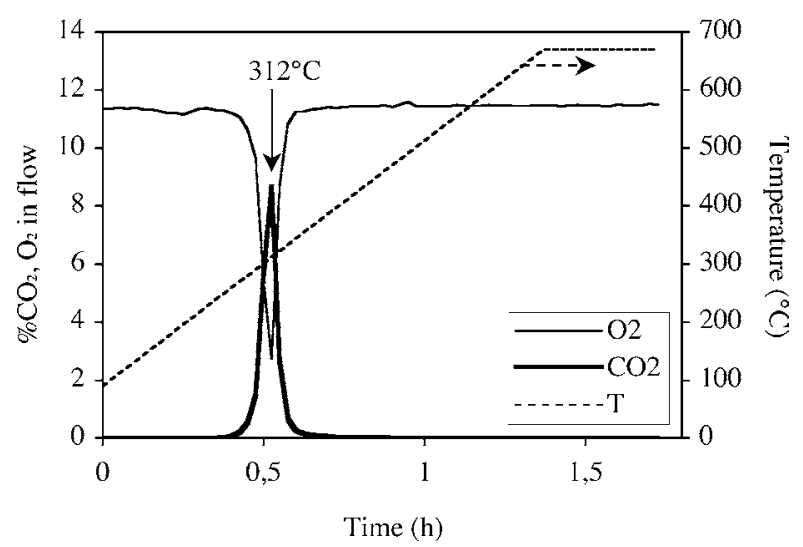

Fig. 11. TPO profile of $\mathrm{Pt} / \mathrm{CeO}_{2}-\mathrm{ZrO}_{2}$ catalyst after activity tests under $\mathrm{O} /$ $\mathrm{C}=1$ and $\mathrm{H}_{2} \mathrm{O} / \mathrm{C}=0$ conditions.
A carbon dioxide peak is observed between 270 and $350{ }^{\circ} \mathrm{C}$, perfectly symmetrical from the oxygen consumption peak. Carbon monoxide is never detected. No oxygen consumption corresponding to the reoxidation of the ceriazirconia support is observed, but this probably occurs as soon as oxygen is contacted with the reduced catalyst at very low temperature: previous studies have shown that this ceria-zirconia support, when supporting platinum or palladium particles, can be reduced and reoxidized at room temperature [11].

Integration of the $\mathrm{CO}_{2}$ curve corresponds to the removal of $23 \mathrm{mg} \mathrm{C} / \mathrm{g}$ catalyst. This amount is very low. The low temperature observed for the combustion of carbon (maximum at $312^{\circ} \mathrm{C}$ ) suggests highly reactive carbonaceous species, in close contact with platinum.

A sintering of both support and platinum, under the reaction conditions required for isooctane reforming, was evidenced by these characterizations. However, the activity quickly reaches stability, suggesting that the catalyst probably undergoes a rapid initial sintering, but does not change much subsequently with time-on-steam. Another important point is that, under conditions where carbon poisoning takes place, the coking remains marginal, which confirms the role of ceria-zirconia supports in preventing carbon deposition.

\section{Conclusions}

The following conclusions can be drawn from the present investigation:

(i) Thermodynamic calculations based on energy and components balances show that the ATR of isooctane is the most efficient when the $\mathrm{O} / \mathrm{C}$ ratio is close to unity 
and the $\mathrm{H}_{2} \mathrm{O} / \mathrm{C}$ ratio around 2-3. Higher $\mathrm{H}_{2} \mathrm{O} / \mathrm{C}$ ratios do not improve the hydrogen yield.

(ii) $\mathrm{A} 2 \mathrm{wt} . \% \mathrm{Pt} / \mathrm{CeO}_{2}-\mathrm{ZrO}_{2}$ catalyst performs well in the ATR of isooctane at high space velocity. Under the experimental conditions defined as optimum by the thermodynamics, the catalytic activity is stable with time-on-steam, and the conversion of isooctane total at $730{ }^{\circ} \mathrm{C}$.

(iii) Compared to pure steam reforming, $\mathrm{O}_{2}$ introduction in the feed gas improves the conversion of isooctane. Up to an $\mathrm{O} / \mathrm{C}$ ratio of 0.75 , the production of hydrogen is also increased, but higher $\mathrm{O} / \mathrm{C}$ ratios favour total oxidation. An $\mathrm{O} / \mathrm{C}$ ratio around $0.75-1$ corresponds to an optimum hydrogen production.

(iv) The production of hydrogen increases regularly with the $\mathrm{H}_{2} \mathrm{O} / \mathrm{C}$ ratio, whereas the conversion of isooctane is only moderately improved. This is related to the displacement of the WGS equilibrium towards $\mathrm{H}_{2}$ formation when the steam contents increases.

(v) An optimised reaction composition, in terms of hydrogen production, corresponds to a $\mathrm{O} / \mathrm{C}$ ratio between 0.5 and 1 , and $\mathrm{H}_{2} \mathrm{O} / \mathrm{C}$ ratio of 2 . Under these conditions, the conversion of isooctane is total at $730{ }^{\circ} \mathrm{C}$, and the hydrogen level reaches $62 \%$ in the reformate. These conditions are close to the calculated thermoneutrality of the reaction.

(vi) The conditions required for isooctane reforming (high temperature, high amounts of steam present) lead to a significant sintering of both ceria-zirconia support and platinum particles. However, the catalytic activity remains stable under reaction conditions, probably because this sintering occurs rapidly at the first catalyst exposure to high temperature in the presence of steam.
The $\mathrm{Pt} / \mathrm{CeO}_{2}-\mathrm{ZrO}_{2}$ catalyst is apparently not poisoned by carbon deposition, provided that both oxygen and steam are present in the feed gas. This suggests that the ceria-zirconia support plays an active role in the transformation of the carbonaceous species, originating from isooctane decomposition, into gaseous products.

\section{References}

[1] A. Docter, A. Lamm, J. Power Sources 84 (1999) 194.

[2] T. Rampe, A. Heinzel, B. Vogel, J. Power Sources 86 (2000) 536.

[3] S. Ayabe, H. Omoto, T. Utaka, R. Kikuchi, K. Sasaki, Y. Teraoka, K. Eguchi, Appl. Catal. A: Gen. 241 (2003) 261.

[4] S. Springmann, M. Bohnet, A. Docter, A. Lamm, G. Eigenberger, J. Power Sources 128 (2004) 13.

[5] Y. Wang, D. Wu, Int. J. Hydrogen Energy 26 (2001) 795.

[6] S. Springmann, G. Friedrich, M. Himmen, M. Sommer, G. Eigenberger, Appl. Catal. A: Gen. 235 (2002) 101.

[7] M. Krumpelt, T.R. Krause, J.D. Carter, J.P. Kopasz, S. Ahmed, Catal. Today 77 (2002) 3.

[8] D.L. Trimm, Catal. Today 49 (1999) 3.

[9] H.-S. Roh, K.-W. Jun, W.-S. Dong, J.-S. Chang, S.-E. Park, Y.-I. Joe, J. Mol. Catal. A: Chem. 181 (2002) 137.

[10] K. Otsuka, Y. Wang, M. Nakamura, Appl. Catal. A: Gen. 183 (1999) 317.

[11] C. Bozo, N. Guilhaume, E. Garbowski, M. Primet, Catal. Today 59 (2000) 33.

[12] B.F. Hagh, J. Power Sources 130 (2004) 85

[13] B.F. Hagh, Int. J. Hydrogen Energy 28 (2003) 1369.

[14] S. Ahmed, M. Krumpelt, Int. J. Hydrogen Energy 26 (2001) 291.

[15] M. Pijolat, M. Dauzat, M. Soustelle, Solid State Ionics 50 (1992) 31.

[16] J.R. Rostrup-Nielsen, Catalytic Steam Reforming, Springer-Verlag, 1984.

[17] J. Sehested, J.A.P. Gelten, I.N. Remediakis, H. Bengaard, J.K. Norskov, J. Catal. 223 (2004) 432. 